\title{
Budgerigar-fancier's lung: the commonest variety of allergic alveolitis in Britain
}

\author{
D J HENDRICK, JENNIFER A FAUX, R MARSHALL
}

British Medical fournal, 1978, 2, 81-84

\section{Summary and conclusions}

A questionnaire survey of 1005 consecutive attenders at four outpatient clinics yielded $117(12 \%)$ budgerigar fanciers (exposed to budgerigars known in North America as parakeets - for at least three months) and $296(29 \%)$ former fanciers. Twenty had precipitins to budgerigar serum or droppings or both, and 10 of these together with 39 precipitin-negative patients reported undue breathlessness on exertion during exposure to budgerigars. These 59 patients were investigated further, seven completing a series of inhalation provocation tests with budgerigar antigens designed to confirm or exclude budgerigar-fancier's lung (BrFL). Typical positive responses were obtained from four current and one former fancier.

The prevalence of confirmed BrFL among the 117 current budgerigar fanciers was $3.4 \%$ (four cases). This was biased, however, by the inclusion of one patient whose attendance at the surveyed clinic was attributable to the disease. With the exclusion of this patient, confidence limits suggested that the true prevalence of BrFL among current budgerigar fanciers in the general population lies between $0.5 \%$ and $7.5 \%$, which is similar to the prevalence of farmer's lung in farm workers. In view of the enormous population at risk, however, this implies that BrFL rather than farmer's lung is by far the commonest type of allergic alveolitis in Britain.

\section{Introduction}

Non-occupational allergic alveolitis was first recorded by Reed et al, ${ }^{1}$ who in 1965 described three cases of pigeon-fancier's lung. In 1966 Hargreave et $a l^{2}$ reported the equivalent condition in budgerigar fanciers. Since then the risks of keeping pigeons have been considered in many studies among the highly organised and medically well-informed pigeon-racing community. ${ }^{3-6}$ In contrast the hazards of keeping budgerigars have received little attention. This is surprising, since for every pigeon fancier (and every four farm workers) in Britain there are about 40 budgerigar fanciers. Furthermore, unlike pigeon fanciers and farm workers, most people living in households keeping budgerigars are totally ignorant of any associated respiratory hazard. This and the usually insidious onset of budgerigar-fancier's lung (BrFL) with slow unremitting progression conspire not only to mask the relevance of the bird but often to delay presentation until a more advanced and largely irreversible stage has been reached.

\footnotetext{
Churchill Hospital and Radcliffe Infirmary, Oxford University, Oxford

D J HENDRICK, MRCP, senior registrar (now assistant professor of medicine, West Virginia University, West Virginia 26506)

JENNIFER A FAUX, PHD, immunologist

R MARSHALL, MD, FRCP, clinical reader in respiratory diseases
}

We have tried to estimate the prevalence of BrFL and assess its importance relative to other types of allergic alveolitis occurring in Britain.

\section{Patients and methods}

Two chest clinics, a general medical clinic, and an orthopaedic clinic were surveyed during 1974-5. These served urban and rural populations of Oxfordshire in roughly equal proportions. At least 250 patients were taken from each source.

\section{QUESTIONNAIRES}

A numbered questionnaire was issued to every patient on arrival asking for details of age, sex, occupations, episodes of bird exposure (periods of at least three months during which the patient had lived in a household keeping a bird or birds, whether indoors or out), smoking, and respiratory symptoms. Each completed questionnaire was checked by the patient with one of three scrutineers, who operated strategically within the clinic waiting area. By this means errors or omissions were minimised.

\section{PRECIPITIN TESTS}

Altogether 247 patients were tested for precipitin reactions (see table III). Of those who had recorded the onset of undue breathlessness while exposed to budgerigars, all but two former fanciers were included. Precipitin tests were carried out with extracts of budgerigar serum and droppings, pigeon serum and droppings, and chicken serum.? Four extracts of budgerigar droppings were used whose antigenic contents differed with the method of collection and duration of extraction. Patients' sera giving reactions to two or more of the four extracts were regarded as positive.

\section{INHALATION PROVOCATION TESTS}

Budgerigar antigens were inhaled from one or more of three sources -namely, nebulised serum (dilutions of $1 / 100-1 / 5$ in carbol-saline) for 5-30 minutes; nebulised droppings (3-20 g/1 in carbol-saline) for 5-30 minutes; and "natural" exposure in a budgerigar aviary for 1-5 hours. Extracts of serum and droppings were sterilised by heating for 30 minutes at $56^{\circ} \mathrm{C}$ and passage through a $0.22 \mu \mathrm{m}$ Millipore membrane. They were inhaled through a facemask and delivered via a Wright nebuliser with an air or oxygen flow of $81 / \mathrm{min}$.

Each patient was exposed on separate days to increasing doses until either an unequivocally positive response was obtained or the arbitarily chosen maximum dose (budgerigar serum $1 / 5$ for $20-30$ minutes nebulising $0.5-1.0 \mathrm{ml}$ neat serum) had produced no response.

The identity of each individual test extract was not disclosed until the whole series (which included control tests with carbol-saline) was completed. After retesting several positive reactors with antigens from one of the other sources we concluded that the maximum-dose serum challenge was equivalent to natural exposure in an aviary of many budgerigars for about 24 hours. Failure to respond at this level was deemed to exclude BrFL.

Before each challenge oral temperature was recorded and blood taken for leucocyte counts. An exercise test was then carried out, the patient walking on a level treadmill at a comfortable constant rate (identical in all subsequent tests) for five minutes. The minute volume was measured by a dry gas meter and the frequency recorded with a pneumotachygraph. Lung volumes and diffusing capacity were also 
measured on earlier patients, but when it was found that these were affected only by unduly strong positive reactions this practice was discontinued. After challenge the oral temperature was taken at intervals of one to two hours and any symptoms were noted. The blood tests and exercise tests were repeated 6-10 hours after the challenge, depending on when any symptoms reached their peak.

\section{Results}

A total of 1005 questionnaires were recovered for joint scrutiny and accepted for analysis. The proportions recovered were $77 \%$ at the chest clinics and $87 \%$ at the two other clinics. Just over half of the patients $(52 \%)$ were male. The mean age was 49 years, and the range 4-85 years (table I).

TABLE I-Age distribution of the 1005 patients

\begin{tabular}{|c|c|c|c|c|c|c|c|c|}
\hline Age (years): & $0-$ & $10-$ & $20-$ & $30-$ & $40-$ & $50-$ & $60-$ & 70 \\
\hline $\begin{array}{l}\text { No of patients } \\
\% \text { of patients }\end{array}$ & $\begin{array}{c}6 \\
0 \cdot 6\end{array}$ & $\begin{array}{l}59 \\
5.9\end{array}$ & $\begin{array}{l}126 \\
12 \cdot 5\end{array}$ & $\begin{array}{l}100 \\
10 \cdot 0\end{array}$ & $\begin{array}{c}154 \\
15 \cdot 3\end{array}$ & $\begin{array}{l}208 \\
20 \cdot 7\end{array}$ & $\begin{array}{c}227 \\
22 \cdot 6\end{array}$ & $\begin{array}{l}125 \\
12 \cdot 4\end{array}$ \\
\hline
\end{tabular}

Bird keeping and farming habits-Table II gives the proportions of patients engaged in farming or recording domestic exposure to budgerigars and pigeons. No exposure to any species of bird was recorded by $377(38 \%)$.

TABLE II-Numbers of patients with current or former exposure to alveolitis hazard. (Percentages in parentheses)

\begin{tabular}{|c|c|c|c|c|c|c|}
\hline \multirow{2}{*}{\multicolumn{4}{|c|}{ Alveolitis hazard }} & \multicolumn{2}{|c|}{ Source of patients } & \multirow{2}{*}{$\begin{array}{c}\text { Total } \\
(\mathrm{n}=1005)\end{array}$} \\
\hline & & & & $\begin{array}{l}\text { Chest clinics } \\
(\mathrm{n}=501)\end{array}$ & $\begin{array}{l}\text { Other clinics } \\
(n=504)\end{array}$ & \\
\hline \multicolumn{7}{|c|}{ Current exposure } \\
\hline $\begin{array}{l}\text { Budgerigar } \\
\text { Pigeon .. } \\
\text { Farming }\end{array}$ & $\begin{array}{l}. \\
\ldots\end{array}$ & $\begin{array}{l}. \\
\cdots\end{array}$ & $\begin{array}{l}. \\
\cdots\end{array}$ & $\begin{array}{cc}66 & (13 \cdot 2) \\
1 & (0 \cdot 2) \\
9 & (1 \cdot 8)\end{array}$ & $\begin{array}{rr}51 & (10 \cdot 1) \\
4 & (0 \cdot 8) \\
8 & (1 \cdot 6)\end{array}$ & $\begin{array}{r}117(11 \cdot 6) \\
5(0.5) \\
17(1 \cdot 7)\end{array}$ \\
\hline \multicolumn{7}{|c|}{ Former exposure } \\
\hline $\begin{array}{l}\text { Budgerigar } \\
\text { Pigeon ... } \\
\text { Farming }\end{array}$ & $\begin{array}{l}\ldots \\
\ldots\end{array}$ & $\begin{array}{l}. \\
\cdots\end{array}$ & $\begin{array}{l}\ldots \\
\cdots\end{array}$ & $\begin{array}{r}158(31 \cdot 5) \\
17(3 \cdot 4) \\
19(3 \cdot 8)\end{array}$ & $\begin{aligned} & 138(27 \cdot 4) \\
& 16(3 \cdot 2) \\
& 14(2 \cdot 8)\end{aligned}$ & $\begin{array}{rr}296 & (29 \cdot 5) \\
33 & (3 \cdot 3) \\
33 & (3 \cdot 3)\end{array}$ \\
\hline
\end{tabular}

Precipitin tests-Three patterns of precipitin reaction were noted (table III). These were common reactions to budgerigar serum and droppings, which are characteristic of $\mathrm{BrFL}^{7}$; a single common reaction to budgerigar, pigeon, and chicken serum, but not to either droppings extract, which is associated with coeliac disease ${ }^{78}$; and reactions to budgerigar droppings alone, which may be unassociated with exposure to budgerigars. ${ }^{9}$ None of the pigeon fanciers gave precipitin reactions to pigeon serum.

Selection for inhalation provocation tests (table IV)-As a result of examinations of hospital records, telephone calls, personal interviews, physical examinations, and, when appropriate, pulmonary function tests coupled with chest radiography BrFL was considered to be a possible cause or contributory factor of breathlessness beginning

TABLE III-Numbers of patients giving positive precipitin reactions to budgerigar serum and droppings (characteristic of $B r F L$ ); budgerigar, pigeon, and chicken serum (associated with coeliac disease); and budgerigar droppings alone (possibly unassociated with exposure) (247 patients tested)

\begin{tabular}{|c|c|c|c|}
\hline Budgerigar exposure & $\begin{array}{c}\text { BrFL-associated } \\
\text { antigens }\end{array}$ & $\begin{array}{c}\text { Coeliac-disease- } \\
\text { associated } \\
\text { antigen }\end{array}$ & $\begin{array}{c}\text { Budgerigar } \\
\text { droppings } \\
\text { alone }\end{array}$ \\
\hline $\begin{array}{l}\text { Current }(n=111) \\
\text { Former }(n=96) \\
\text { No bird exposure }(n=40)\end{array}$ & $6^{*}$ & $\begin{array}{l}2 \\
2\end{array}$ & $\begin{array}{l}8 \\
2 \\
1\end{array}$ \\
\hline
\end{tabular}
*In two of these patients precipitins were found in concentrated serum only. One of during budgerigar exposure in nine current and five former fanciers. Of these, six current and three former fanciers together with four precipitin-positive patients who recorded that they were either free of undue breathlessness or had developed it before budgerigar exposure were considered suitable for definitive inhalation provocation tests. Data on the seven patients and two controls (two of us) who completed these tests satisfactorily are given in table V.

Inhalation provocation tests-Four current and one former budgerigar fancier gave between them nine typical positive responses to the

TABLE IV-Interrelations between current or former budgerigar exposure, precipitin reactions, and breathlessness

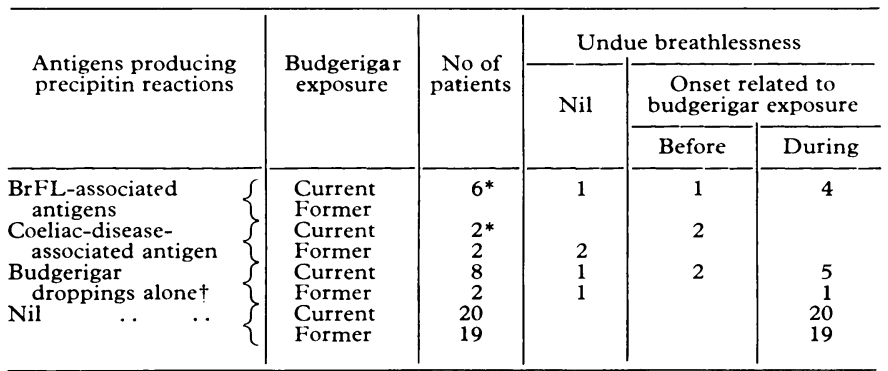

* One patient included in both categories

tOne additional patient had never been exposed to birds and had no respiratory symptoms.

inhalation tests (table V). Influenza-like symptoms (fever, malaise, anorexia, generalised aching) predominated, but dry cough, breathlessness on exertion, and an apparent difficulty in taking a deep satisfying breath generally occurred. Reactions usually began two to eight hours after challenge was started and usually cleared spontaneously within $24-48$ hours. Table VI summarises the results. The two positive reactors who were previously unaware of undue breathlessness or had developed it before budgerigar exposure rid themselves of their birds and acquired an appreciable increase in exercise tolerance.

Prevalence of $B r F L$ - The prevalence of confirmed BrFL among the 117 current budgerigar fanciers was $3.4 \%$ (four cases). This was biased by the inclusion of one patient (case 1 ; table V) whose clinic referral was directly attributable to the disease. The remaining three patients were attending for other reasons-namely, bacteriologically proved past pulmonary tuberculosis in one patient attending a chest clinic, and blood-loss iron-deficiency anaemia in two patients attending other clinics. In estimating the prevalence of $\mathrm{BrFL}$ among current budgerigar fanciers in the general population case 1 was excluded and $95 \%$ confidence limits were applied to the remaining proportionthat is, three of 116 . These suggested that the true prevalence lay between $0.5 \%$ and $7.5 \%$. The prevalence among the former fanciers was appreciably less, only one of the 296 having been proved to have $\mathrm{BrFL}$. One other former fancier was to have undergone the provocation tests but was deterred by an apparently strongly positive response to an unsupervised experimental exposure in a friend's aviary. Both these patients attended chest clinics for reasons unrelated to BrFL.

\section{Discussion}

We have found inhalation provocation tests to be the most reliable method of confirming or excluding BrFL. The characteristic physical signs, chest radiographic appearances, disturbances of pulmonary function, and even lung biopsy establish only a diagnosis of fibrosing alveolitis, and these features may be unimpressive in the earlier stages of the disease when, nevertheless, typical positive results may be obtained from challenge tests. Although precipitins to BrFLassociated antigens are useful diagnostic pointers, confirmation of underlying avian hypersensitivity cannot be assumed from their presence. We have observed positive reactions to inhalation tests in BrFL-precipitin-negative patients, and vice versa.

For these reasons we have based our prevalence estimates only on those patients proved to have $\mathrm{BrFL}$ by inhalation provocation 
TABLE $\mathrm{V}-$ Details of subjects undergoing inhalation provocation tests

\begin{tabular}{|c|c|c|c|c|c|c|c|}
\hline \multirow{2}{*}{$\begin{array}{c}\text { Subjects } \\
\text { tested }\end{array}$} & \multirow{2}{*}{$\begin{array}{l}\text { Sex } \\
\text { and } \\
\text { age }\end{array}$} & \multirow{2}{*}{ Budgerigar exposure } & \multirow{2}{*}{ Precipitin category } & \multirow{2}{*}{$\begin{array}{l}\text { Onset of breathlessness } \\
\text { related to budgerigar } \\
\text { exposure }\end{array}$} & \multicolumn{3}{|c|}{ No of active challenges: } \\
\hline & & & & & Negative & Equivocal & Positive \\
\hline \multicolumn{8}{|c|}{ Patients } \\
\hline 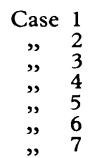 & $\begin{array}{ll}F & 67 \\
M & 42 \\
F & 34 \\
M & 55 \\
F & 56 \\
M & 46 \\
F & 56\end{array}$ & $\begin{array}{l}\text { Current } \\
\text { Current } \\
\text { Current } \\
\text { Current } \\
\text { Current } \\
\text { Former } \\
\text { Former }\end{array}$ & $\begin{array}{l}\text { BrFL } \\
\text { BrFL } \\
\text { BrFL* } \\
\text { BrFL,* + coeliac } \\
\text { Droppings } \\
\text { Coeliac } \\
\text { Nil }\end{array}$ & \begin{tabular}{|l} 
During \\
Nil \\
During \\
Before \\
Before \\
Nil \\
During
\end{tabular} & $\begin{array}{l}2 \\
3 \\
1 \\
2 \\
4 \\
3 \\
1\end{array}$ & $\begin{array}{l}1 \\
1 \\
1\end{array}$ & $\begin{array}{l}1 \\
2 \\
2 \\
3 \\
\\
1\end{array}$ \\
\hline \multicolumn{8}{|c|}{ Controls } \\
\hline $\begin{array}{l}\text { A } \\
\text { B }\end{array}$ & $\begin{array}{l}\text { M } 34 \\
M \quad 54\end{array}$ & $\begin{array}{l}\text { Former } \\
\text { Nil† }\end{array}$ & $\begin{array}{l}\text { Nil } \\
\text { Nil }\end{array}$ & $\begin{array}{l}\text { Nil } \\
\text { Nil }\end{array}$ & $\begin{array}{l}5 \\
4\end{array}$ & & \\
\hline
\end{tabular}

*On concentration only.

†Chicken formerly.

TABLE VI-Results of inhalation provocation tests

\begin{tabular}{|c|c|c|c|c|c|c|c|c|c|}
\hline \multirow[t]{2}{*}{ Subjects tested } & & \multirow{2}{*}{$\begin{array}{l}\text { No of } \\
\text { tests }\end{array}$} & \multirow{2}{*}{$\begin{array}{c}\text { No of } \\
\text { symptoms }\end{array}$} & \multicolumn{2}{|c|}{$\begin{array}{c}\text { Maximum temperature } \\
\text { after challenge } \\
\left({ }^{\circ} \mathrm{C}\right)\end{array}$} & \multicolumn{2}{|c|}{$\begin{array}{l}\text { Change in neutrophil } \\
\text { count } \\
\left(\times 10^{9} / 1\right)\end{array}$} & \multicolumn{2}{|c|}{$\begin{array}{c}\text { Change in minute } \\
\text { volume } \\
(\%)\end{array}$} \\
\hline & & & & Range & Mean & Range & Mean & Range & Mean \\
\hline $\begin{array}{l}\text { Positive reactors }(n=5): \\
\text { Control challenges } \\
\text { Active challenges (positive) } \\
\text { Negative reactors }(n=4): \\
\text { Active challenges (negative) }\end{array}$ & $\begin{array}{l}\cdots \\
\cdots \\
\ldots\end{array}$ & $\begin{array}{r}6 \\
9 \\
16\end{array}$ & 9 & $\begin{array}{l}36 \cdot 2 \text { to } 36 \cdot 9 \\
37 \cdot 1 \text { to } 38 \cdot 9 \\
35.6 \text { to } 37.0\end{array}$ & $\begin{array}{l}36 \cdot 7 \\
37 \cdot 6 \\
36 \cdot 5\end{array}$ & $\begin{array}{l}-2.97 \text { to }+1.59 \\
+0.41 \text { to }+9.98 \\
-1.42 \text { to }+1.8\end{array}$ & $\begin{array}{l}-0 \cdot 78 \\
+4 \cdot 51 \\
+0.36\end{array}$ & $\begin{array}{l}-19 \text { to }+3 \\
+10 \text { to }+43 \\
-22 \text { to }+9\end{array}$ & $\begin{array}{l}-3 \\
+23 \\
-\quad 1\end{array}$ \\
\hline
\end{tabular}

tests. We have carried out over 140 of these tests on 35 individuals and found the results to be reliable and reproducible. The identical nature of the positive responses obtained from both serum and droppings extracts as well as from natural aviary exposure does much to confirm their validity, especially as they are in addition indistinguishable from the positive responses we have obtained from "occupational" challenges in patients with farmer's lung and mushroom-worker's lung.

Since provocation tests were not carried out on all patients suspected of having BrFL, possibly the actual prevalence among the current fanciers exceeded $3.4 \%$. Not all unchallenged fanciers in whom BrFL was considered to be possible, however, showed convincing evidence of diffuse parenchymal pulmonary disease, and when this was unquestionably present other acceptable diagnoses were generally available. Because the population sampled was relatively small, the confidence limits appropriate to our estimates regarding the prevalence of $\mathrm{BrFL}$ in the population at large are wide. They suggest that the true prevalence of $\mathrm{BrFL}$ among current budgerigar fanciers lies between $0.5 \%$ and $7.5 \%$.

Symptoms strongly suggestive of farmer's lung may occur in up to $10 \%$ of agricultural workers, Grant et al ${ }^{10}$ having estimated the risks to be higher in areas of high rainfall-for example, Ayrshire, prevalence $8.6 \%$ - and in areas where traditional farming methods persist-for example, Orkney, prevalence $8.6 \%$-than in drier regions using more modern methods, which are probably the most representative of British farming-for instance, East Lothian, prevalence $2.3 \%$. Madsen et $a l^{11}$ found a prevalence of $2.9 \%$ among a Wyoming farming community. Other survevs suggesting the prevalence of farmer's lung to be substantially less took account only of subjects sufficiently distressed and motivated to seek medical advice. The four cases discovered by Grant et al among 148 East Lothian farm workers suggested a true prevalence of between $0.5 \%$ and $6.5 \%$. This is similar to that of BrFL among current budgerigar fanciers predicted from the present study.

The prevalence of pigeon fancier's lung has proved difficult to estimate, largely because an appreciable proportion of pigeon fanciers are unwilling to co-operate with studies they fear may ultimately force them to give up their hobby. Fink $e t a l^{4}$ found no significant excess of respiratory symptoms or disturbances of pulmonary function among 200 pigeon fanciers and concluded that the prevalence of pigeon-fancier's lung was low since no cases were detected. Other workers have suggested prevalences of $6 \%{ }^{5}$ and $8 \%,{ }^{3}$ while Christensen et al found evidence suggestive of pigeon-fancier's lung in $21 \%$ of members of a Utah pigeon club. Of the 38 pigeon fanciers identified in the present survey, in only one former fancier was pigeon-fancier's lung suspected.

From the evidence available it is not clear whether the respective risks of developing allergic alveolitis from budgerigars, pigeons, or farm dusts are appreciably different. It seems unlikely. Almost $0 \cdot 3 \%$ of the British population keep pigeons, ${ }^{12}$ and $1.1 \%$ work in farming, ${ }^{13}$ which is rather less than in Oxfordshire. In contrast, 5-6 million homes in Britain are said to harbour budgerigars, ${ }^{14}$ and so the great popularity of budgerigar keeping noted in this study appears to be representative of the whole country. Thus if $12 \%$ of the general population is exposed to budgerigars between 65 and 900 per 100000 are likely to be affected by BrFL, albeit mildly in most cases. We therefore cannot agree with the widely held view that farmer's lung is the most common form of allergic alveolitis in Britain. ${ }^{101516}$ We believe that BrFL is about ten times more common by virtue of the far greater population at risk, and these conclusions are supported by our overall experience in Oxford during 1973-6.

We are grateful to our colleagues Drs J M Black, W S Hamilton, and D J Lane, of the chest department, Churchill Hospital; Drs $S$ Callender and R C Turner, of the Nuffield Department of Medicine, Radcliffe Infirmary; and Mr J Goodfellow, of the Nuffield Orthopaedic Centre, Oxford, for kindly allowing us to study patients under their care. Our thanks are also due to our former secretary Miss $\mathrm{T}$ Drysdale, who acted as a scrutineer; Drs P Green, $\mathrm{H}$ Armitage, and D Howes for carrying out differential leucocyte counts; the staff of the Oxford Region Computer Centre for help in processing data; and Dr J Krall, of the department of community medicine, West Virginia University, for statistical advice. We acknowledge a great debt to those of our patients who cheerfully submitted themselves, 
often repeatedly, to extremely time consuming tests that they knew could provoke uncomfortable symptoms. Financial help was provided by a research grant from the Oxford RHA(T).

\section{References}

${ }^{1}$ Reed, C E, Sosman, E, and Barbee, R D, fournal of the American Medical Association, 1965, 193, 261.

2 Hargreave, F E, et al, Lancet, 1966, 1, 445.

${ }^{3}$ Elgefors, D, Belin, L, and Hanson, L A, Scandinavian fournal of Respiratory Diseases, 1971, 52, 167.

${ }^{4}$ Fink, J N, et al, Chest, 1972, 62, 277.

${ }^{5}$ Caldwell, J R, et al, fournal of Allergy and Clinical Immunology, 1973, 52, 225.
${ }^{6}$ Christensen, L T, Schmidt, C D, and Robbins, L, Clinical Allergy, 1975, $5,417$.

7 Faux, J A, Hendrick, D J, and Anand, B, Clinical Allergy. 1978, 8, 101. ${ }^{8}$ Hendrick, D J, et al, Thorax. In press.

${ }^{9}$ Faux, J A, et al, Clinical and Experimental Immunology, 1970, 7, 897.

${ }^{10}$ Grant, I W B, et al, British Medical fournal, 1972, 1, 530.

${ }_{11}$ Madsen, D, et al, American Review of Respiratory Diseases, 1976, 113, 171.

12 Royal Pigeon Racing Association, personal communication, 1977.

13 Central Statistics Office, Social Trends, No 5, table 39. London, HMSO, 1974.

14 The Budgerigar Society, personal communication, 1977.

${ }^{15}$ Parkes, W R, in Occupational Lung Disorders, p 392. London, Butterworths, 1974.

${ }^{16}$ Edwards, J H, Wagner, J C, and Seal, R M E, Clinical Allergy, 1976, 6, 155.

(Accepted 6 April 1978)

\title{
Axillary hyperhidrosis treated with alcoholic solution of aluminium chloride hexahydrate
}

\author{
K T SCHOLES, K D CROW, J P ELLIS, R R HARMAN, E M SAIHAN
}

British Medical fournal, 1978, 2, 84-85

\section{Summary and conclusions}

Sixty-five patients with axillary hyperhidrosis took part in a trial of treatment with a solution of $20 \%$ aluminium chloride hexahydrate in absolute alcohol, applied topically each night for a week and then whenever the patient thought it necessary. Excellent control of sweating was achieved in 64 patients, and occlusion of the area was found to be unnecessary. No troublesome side effects were reported.

The results of this study indicate that $20 \%$ aluminium chloride hexahydrate in absolute alcohol is the treatment of first choice for patients with axillary hyperhidrosis.

\section{Introduction}

Axillary hyperhidrosis is socially embarrassing and financially taxing: suits, shirts, and dresses may be soon ruined by it. Most sufferers are extremely conscious of the wet patches evident in their axillae on important social occasions. The main feature of the disorder is a massive outpouring of secretions from the eccrine sweat glands under thermal and emotional stress. It is virtually unknown before adolescence, and many patients seem to undergo spontaneous remission after middle age.

Many forms of treatment have been advocated, which were well reviewed by Cunliffe and Tan. ${ }^{1}$ There are four main types: systemic, surgical, radiotherapeutic, and topical. Systemic treatment consists mainly of anticholinergic drugs such as propantheline. These often have to be given in high dosage, causing severe side effects with little control of axillary sweating.

\footnotetext{
Department of Dermatology, Princess Margaret Hospital, Swindon SN1 4JU

K T SCHOLES, MB, CHB, clinical assistant

K D CROW, MB, FRCP, consultant dermatologist

J P ELLIS, MB, MRCP, consultant dermatologist

Department of Dermatology, Bristol Royal Infirmary, Bristol BS2 8HW

R R HARMAN, MB, FRCP, consultant dermatologist

E M SAIHAN, MB, MRCP, registrar
}

Various operative procedures described include cervical sympathectomy, ${ }^{2}$ total excision, ${ }^{3}$ or curettage ${ }^{4}$ of the eccrine glands, and cryotherapy. ${ }^{5}$ Ellis ${ }^{6}$ advocated total excision of the eccrine glands as the treatment of choice. The initial success rate of this procedure appears to be low, however, recurrence is high, and scarring may be severe. Radiotherapy has also been used, ${ }^{7}$ but the high dose needed to eliminate sweating may cause radiodermatitis. Many topical preparations have been in common usage from the early part of the century: Shelley and Hurley; listed almost 90 , most of which were aluminium salts. Their mode of activity is not known, but they affect the eccrine gland and duct below the level of the stratum corneum rather than plugging the sweat pore. ${ }^{8}{ }^{9}$ These preparations have been used extensively commercially but are usually buffered towards a neutral $\mathrm{pH}$ to minimise irritation of the skin and damage to clothing, which makes them more acceptable. They appear to control sweating in normal people but do not help those with hyperhidrosis.

Shelley and Hurley ${ }^{7}$ maintained that a high acidity $(\mathrm{pH}<1)$ was essential in treating patients with hyperhidrosis, and claimed success in five cases in which a $25 \%$ solution of aluminium chloride hexahydrate in absolute alcohol was used. Their work seems to have been largely overlooked, but their results were encouraging and we felt they justified further study, particularly in view of the cases reported by Sneddon. ${ }^{10}$

\section{Patients and methods}

Over 15 months we treated 65 patients with axillary hyperhidrosis in our dermatology clinics (42 in Swindon and 23 in Bristol). The group comprised 57 women and eight men aged $14-51$ years. They had suffered from axillary hyperhidrosis for from two to 25 years. Many had had previous treatments. In particular, three had undergone excision of the eccrine glands, and one had been treated with sympathetic block and radiotherapy. The diagnosis of axillary hyperhidrosis was made from the patient's history and close observation of the axilla at consultation. In every case the sweat soaked through clothing.

Our methods were based on those outlined by Shelley and Hurley,? using $20 \%$ aluminium chloride hexahydrate dissolved in absolute alcohol. This is an almost saturated solution and takes three weeks to dissolve at room temperature. The solution was applied nightly with a small brush. It was important that the axilla was dry before application and not shaved for 24 hours before and after treatment. The solution was applied only to the area of excessive sweating. At the beginning of the study the patients were instructed to occlude the 